\title{
IFI16 wt Allele
}

National Cancer Institute

\section{Source}

National Cancer Institute. IFl16 wt Allele. NCI Thesaurus. Code C115027.

Human IFI16 wild-type allele is located in the vicinity of $1 \mathrm{q} 22$ and is approximately $55 \mathrm{~kb}$ in length. This allele, which encodes gamma-interferon-inducible protein 16, is involved in both transcriptional regulation and immunity-mediated cell death. 